\title{
STRATEGI PEMBERDAYAAN SOFT SKILLS PENYANDANG DISABILITAS DI DEAF CAFÉ AND CAR WASH CINERE DEPOK JAWA BARAT
}

\author{
Septiani Rachmawati, Muhtadi \\ Prodi Pengembangan Masyarakat Islam Fakultas Ilmu Dakwah dan Ilmu Komunikasi \\ Universitas Islam Negeri Syarif Hidayatullah Jakarta \\ Email: Septianirachmawatu3@gmail.com
}

\begin{abstract}
Abstrak
Persepsi terhadap penyandang disabilitas sebagai orang yang tidak dapat melakukan pekerjaan sebagaimana non disabilitas membuat mereka sulit untuk mendapat pekerjaan. Dengan kekurangan yang ada pada penyandang disabilitas dianggap sebagai penghambat dalam bekerja dan sulit dalam membangun komunikasi dengan penyandang disabilitas tunarungu. Penyandang disabilitas membutuhkan tempat untuk mewadahi mereka mendapatkan pendidikan dan pelatihan, motivasi yang selalu diberikan, komunikasi yang baik, saran dan prasarana yang mendukung keadaan para penyandang disabilitas. Penelitian ini bertujuan untuk mengetahui (1) strategi yang dilakukan di Deaf Café and Car Wash Fingertalk Cinere, (2) hasil dari pemberdayaan yang dilakukan. (3) factor pendukung dan penghambat dalam pelaksanaan pemberdayaan. Metode penelitian ini menggunakan pendekatan kualitatif dengan menggunakan data dari hasil observasi, wawancara, dan dokumentasi. Hasil penelitian menunjukkan pemberdayaan yang diberikan telah memberikan perubahan bagi penyandang disabilitas menjadi berdaya dengan skill yang dimiliki, mandiri, dan percaya diri.
\end{abstract}

\section{Kata Kunci: strategi pemberdayaan; penyandang disabilitas; pelatihan keterampilan}

\section{Abstract}

The perception of persons with disabilities as people who cannot do work like non-disabled people makes it difficult for them to find work. With existing deficiencies, people with disabilities are considered to be an obstacle to work and it is difficult to build communication with people with hearing disabilities. Persons with disabilities need a place to accommodate them to get education and training, always given motivation, good communication, advice and infrastructure that supports the situation of persons with disabilities. This study aims to determine (1) the strategy carried out at Deaf Café and Car Wash Fingertalk Cinere, (2) the results of the empowerment carried out, (3) the supporting and inhibiting factors in the implementation of empowerment. This research method uses a qualitative approach using data from observations, interviews, and documentation. The results showed that the empowerment provided has made changes for people with disabilities to become em powered with their own skills, independence, and self-confidence.

Keywords: empowerment straTegy; persons with disabilities; skills training. 


\section{PENDAHULUAN}

Persepsi terhadap penyandang cacat sebagai orang yang tidak berguna mengalir begitu saja sejak keadaan mereka dianggap sudah tidak memiliki peran dan fungsi dengan sempurna bagi kehidupan sosial maupun kehidupan pribadi mereka. Aspek yang sangat problematis dari suatu disabilitas adalah pandangan sosial tentang analisis fungsional kesehatan dan penyakit. Teori sosial abad ke dua puluh mengidentifikasi penyandang cacat sebagai orang yang tidak memiliki kesempurnaan baik fisik, alat sensoris, maupun fungsi kognisi dan oleh karena itu tidak dapat untuk memenuhi tugas dan peran sosial. Ketidaksempurnaan kapasitas ini menjadikan mereka semakin tergantung kepada orang yang sempurna dan produktif .

Melihat keadaan tersebut menjadikan pandangan negatif dikalangan masyarakat terhadap para penyandang disabilitas semakin meluas dan membuat para penyandang disabilitas semakin tertindas kemudian terdiskriminasi dari lingkungannya seperti dalam bergaul, berkomunikasi, pekerjaan, pendidikan dan lainnya. Dan hal itu membuat para penyandang disabilitas semakin merasa tidak percaya diri dan merasa bahwa mereka tidak ada dilingkungan mereka sendiri. Dengan keterbatasan yang dimiliki penyandang disabilitas membuat mereka kesulitan dalam mendapatkan hak-hak yang sama seperti kelompok lainnya (non disabilitas).

Para penyandang disabilitas seharusnya memiliki hak-hak dan kesempatan yang sama seperti yang lainnya untuk mendapatkan pekerjaan yang layak. Sebagaimana tampak jelas tercantum dalam Undang-Undang Nomor 8 Tahun 2016 Tentang Penyandang Disabilitas bab III pasal 5 ayat 1 bahwa penyandang disabilitas memiliki hak: pekerjaan, kewirausahaan, dan koperasi. Pasal 27 ayat (2) UUD 1945 yaitu: "Tiap-tiap warga Negara berhak atas pekerjaan dan penghidupan yang layak bagi kemanusiaan”. Dalam Pasal 28D ayat (2) UUD 1945 yaitu: "Setiap orang berhak bekerja serta mendapat imbalan dan perlakuan yang adil dan layak dalam hubungan kerja."

${ }^{1}$ Colin Barnes dan MererGeof , Disabilitas: SuAtu PenGAntAr. Penerjemah: Siti Napsiyah,dkk. Jakarta: PIC UIN Jakarta, 2007. 
Berdasarakan Undang-Undang di atas, penyandang disabilitas memiliki kesempatan yang sama dalam segala aspek kehidupan. Termasuk di dalamnya mengenai pekerjaan dan kehidupan yang layak. Untuk mencapai hal tersebut para disabilitas membutuhkan sebuah wadah yang dapat membangun dan mengembangkan kemampuan atau kreatifitas yang mereka miliki. Berkenaan dengan hal ini, di daerah Cinere, Tanggerang Selatan terdapat sebuah kafe yang bernama Deaf Café and Car Wash Fingertalk. Kafe yang didirikan seorang perempuan muda yang bernama Mba Dissa Sakina Ahdanisa ini merupakan sebuah kafe yang bertujuan untuk memberdayakan penyandang disabilitas khususnya tunarungu. Dengan melihat potensi yang ada penyandang disabilitas maka pemberdayaan yang diberikan dengan memberikan pelatihan skill atau keterampilan. Sehingga potensi yang ada pada penyandang disabilitas dapat berkembang.

Adapun beberapa penelitian yang membahas terkait tema penelitian ini ialah sebagai berikut: PertamA, penelitian yang ditulis oleh Andy Setyawan yang membahas mengenai "Komunikasi Antar Pribadi Nonverbal Penyandang Disabilitas di DeAF Fingertalk" menuju percontohan pola komunikasi penyangdang disabilitas sebagai pegawai kafe dengan customer. KeduA, penelitian yang ditulis oleh Iffatus Sholehah yang membahas mengenai "Pemberdayaan Difabel Melalui Asset Bassed Approach" menuju percontohan pemberdayaan disabilitas dengan menggunakan analisis melalui Asset Based Approach.

Berdasarkan latar belakang di atas, maka dapat ditarik rumusan masalah sebagai berikut: bagamana strategi yang dilakukan dalam memberdayakan penyandang disabilitas, apa hasil yang didapat dari pemberdayaan yang dilakukan, dan apa faktor pendukung dan penghambat yang dialami dalam pelaksanaan pemberdayaan yang dilakukan di Deaf Café and Car Wash Fingertalk Cinere.

\section{METODE PENELITIAN}

Penelitian ini menggunakan metode penelitian kualitatif berdasarkan apa yang ada di lapangan. Teknik pengumpulan data dalam 
penelitian ini yaitu wawancara, observasi, dan dokumentasi yang didukung oleh data kepustakaan. Narasumber penelitian ini adalah pengurus kafe dan penyandang disabilitas di Deaf Café and Car Wash Fingertalk Cinere.

\section{HASIL DAN PEMBAHASAN}

\section{Strategi Pemberdayaan Penyandang Disabilitas}

Pemberdayaan menurut Irwin (L.Hayar Satar, 1992) ${ }^{2}$ pemberdayaan adalah proses memberikan kesempatan dan menciptakan berbagai kontribusi khusus dalam bentuk wawasan, keterampilan-keterampilan, energi tertentu atau dalam bentuk memberikan perhatian kepada sesama.

Menurut Marrus (Umar, 2001) ${ }^{3}$ strategi merupakan tindakan yang bersifat incremental (senantiasa meningkat) dan terus- menerus, serta dilakukan berdasarkan sudut pandang tentang apa yang diharapkan oleh para pelanggan di masa depan.

Penyandang disabilitas sebagai orang atau kelompok yang memiliki kekurangan, bagi para disabilitas yang kurang beruntung seringkali dipandang sebelah mata dan dianggap tidak dapat melakukan pekerjaan dengan baik sebagaimana non disabilitas serta kesulitan mereka dalam berkomunikasi dengan orang lain membuat mereka sulit mendapatkan pekerjaan dan menjadikan mereka tidak percaya diri. Hal ini lah yang menjadikan mba Dissa mendirikan Deaf Café and Car Wash Fingertalk untuk memberikan kesempatan para disabilitas mendapatkan bimbingan, pelatihan, dan pekerjaan serta membuat mereka agar bisa percaya diri.

\section{A. Proses Pemberdayaan}

Dalam proses tahapan pemberdayaan terdapat tiga tahapan yaitu,

${ }^{2}$ Satar, L. Hayat A, 1992, Pemberdayaan Masyarakat Desa, Studi Kasus Peran Pemerintah Dalam Pemberdayaan Pengrajin Gerabah di Desa Penujok, Kecamatan Prayo Barat Kabupaten Lombok Tengah Propinsi NusaTenggara Barat, Tesis MAP UGM. Hal. 21

${ }^{3}$ Umar, H. 2001. Strategic Management in Action, Konsep, Teori, dan Teknik Menganalisis Manajemen Strategis Strategic Business Unit Berdasarkan Konsep Michael R. Porter, Fred R. David, dan Wheelan-Hunger. Jakarta:PT Gramedia Pustaka Utama hal. 31 
tahap penyadaran, tahap transformasi pengetahuan dan kecakapan keterampilan, dan tahap peningkatan kemampuan intelektual dan kecakapan keterampilan. Dalam pemberdayaan yang dilakukan di Deaf Café and Car Wash Fingertalk dimulai dengan menyadarkan para disabilitas tunarungu dengan memberikan motivasi agar para disabilitas bersemangat melakukan perubahan pada dirinya dan percaya diri berhubungan dengan siapapun. Kemudian memberikan pengetahuan mengenai cara berkomunikasi, menyambut dan menghadapi customer, menyajikan pesanan customer dan pelatihan keterampilan memasak, menjahit, mencuci kendaraan. Setelah itu, mengimplementasikan pengetahuan yang diberikan dengan membiarkan para disabilitas bekerja, menghadapi customer sendiri agar terlatih dan terbiasa namun tetap di awasi dan dibantu jika dibutuhkan.

\section{Menghadirkan kembali pengalaman yang memberdayakan dan tidak memberdayakan}

Seperti yang dikatakan Hogan, proses pemberdayaan yang berkesinambungan yaitu, menghadirkan kembali pengalaman yang memberdayakan dan tidak memberdayakan. Hal ini dapat di lihat dari pengalaman para penyandang disabilitas, sebelum bergabung di Deaf Café and Car Wash Fingertalk para disabilitas telah memiliki pengalaman pekerjaan. Ada yang bekerja sebagai penjaga warteg, jualan bersama orangtua nya, konveksi jahit, dan kondektur angkutan umum. Dengan pengalaman tersebut dapat di katakan menjadi pengalaman yang memberdayakan bagi para disabilitas karena dengan pengalamannya membuat mereka selain memiliki pengalaman juga memiliki skill atau kemampuan dalam melakukan suatu hal atau pekerjaan.

Meskipun begitu, sebagaimana yang telah di katakan para penyandang disabilitas banyak dari mereka yang merasa tidak nyaman dengan pekerjaannya dikarenakan ketidak mampuannya ataupun tidak betah dengan pekerjaannya. Ada juga diantara disabilitas yang memang sulit untuk mendapat pekerjaan karena masih meluasnya stigma negatif masyarakat terhadap para penyandang disabilitas yang di anggap tidak dapat bekerja sebagaimana non disabilitas lainnya. 
Maka melihat masih banyaknya disabilitas yang kurang beruntung dan tidak diperhatikan serta pengalaman pekerjaan yang tidak sesuai dengan para disabilitas, maka sebagaimana teori pemberdayaan menurut Irwin, Deaf Café and Car Wash Fingertalk hadir menjadi wadah bagi para penyandang disabilitas khususnya tunarungu agar mendapat kesempatan belajar dan bekerja sehingga menjadikan mereka berdaya secara kemampuan, kemandirian, dan perekonomiannya.

Melihat potensi dan latar belakang pekerjaan para penyandang disabilitas sebelumya menjadi tolak ukur dalam menentukan bentuk pemberdayaan yang diberikan. Dengan potensi dan latar belakang tersebut maka mba Dissa memberdayakan dengan memberikan pelatihan skill keterampilan yang dapat dilakukan oleh para disabilitas. Pemberdayaan tersebut dimulai dengan merekrut para disabilitas melalui iklan di sosial media oleh mba Dissa dan pengurus lainnya dan pesan broadcast yang disebarkan kepada deAF community dengan bantuan ibu Pat. Kemudian para disabilitas yang diterima diberikan motivasi melakukan perubahan dan pengembangan diri dalam belajar dan bekerja melalui pelatihan yang diberikan sehingga mereka memiliki skil dan semakin meningkat skill yang telah ada. Sehingga menjadikan para disabilitas berdaya dan mendapat pekerjaan dengan menjadi pegawai kafe di Deaf Café and Car Wash Fingertalk dan dapat memiliki penghasilan sendiri. Dengan pekerjaan tersebut membuat mereka memiliki penghasilan sendiri.

\section{Mendiskusikan alasan mengapa terjadi pemberdayaan}

Penyandang disabilitas sebagai orang yang memiliki keterbatasan fisik maupun mental seringkali banyak dari mereka kurang beruntung dan sulit mendapatkan pekerjaan yang sesuai dengan mereka. Karena hal itu menjadikan mereka tidak percaya diri dan bergantung kepada orang lain. Untuk para disabilitas mendapat tempat bekerja yang nyaman dan dihargai tidaklah mudah. Banyak dari mereka tidak menemukan pekerjaan yang sesuai. Hal ini tidak selaras dengan UU No.4 Tahun 1997 tentang Penyandang Cacat, Pasal 27 ayat (2) UUD 1945, Pasal 28D ayat (2) UUD 1945 yang mana para penyandang 
disabilitas semestinya mendapatkan perlakuan yang adil, kesempatan pekerjaan, dan penghidupan layak. Seperti yang dialami mas Auf atau Ma'ruf yang berasal dari Ciamis, menurut mas mas Auf, ia merupakan lulusan terbaik dari SLB di Ciamis dan memiliki skill memasak, olahraga tetapi ditolak ketika melamar pekerjaan dikarenakan ia seorang tunarungu.

Ketidak selarasan di atas menjadi alasan didirikannya Deaf Café and Car Wash Fingertalk bagi para penyandang disabilitas supaya mendapat kesempatan yang sama, hak yang sama dalam pekerjaan, kemandirian, serta rasa percaya diri mereka. Dalam pelaksanaan pemberdayaan ini dikhususkan kepada penyandang disabilitas tunarungu yaitu yang mengalami keterbatasan dalam pendengarannya. Keterbatasan tersebut membuat para penyandangnya sulit berkomunikasi dengan orang lain, sulit memahami pesan yang disampaikan orang lain secara lisan, dan mereka kesulitan dalam menyampaikan serta mengekspresikan perasaan mereka dan hal ini membuat mereka sulit mengembangkan diri dan berperan aktif dilingkungan. Seperti yang disampaikan Mas Ali sebagai manajer operasional bahwa para penyandang tunarungu ini selalu merasa tidak percaya diri karena sulitnya memahami dan dipahami oleh orang lain maka Deaf Café and Car Wash Fingertalk ini sebagai jembatan antara para penyandang tunarungu dengan orang biasa.

\section{Mengidentifikasi proyek dan mengidentifikasi basis daya yang bermakna untuk melakukan perubahan}

Meskipun penyandang disabilitas dianggap sebagai orang yang memiliki keterbatasan dan tidak dapat melakukan pekerjaan sebagaimana non disabilitas tetapi mereka masih dapat melakukan kegiatan atau pekerjaan dengan anggota tubuh lainnya yang dapat dijadikan kelebihan bagi mereka, hal ini terlihat dari pengalaman para disabilitas yang pernah bekerja sebelumnya. Menurut Mas Ali, para disabilitas lebih dominan kepada pekerjaan yang berkaitan dengan skill atau keterampilan dibandingkan dengan analisis karena mereka lebih mengandalkan panca indera mata, tangan, dan lainnya.

Seperti yang dikatakan Rousoltone (Kusmana \& Napsiyah, 2007) ${ }^{4}$ bahwa

\footnotetext{
${ }^{4}$ Ibid.
} 
penyandang disabilitas secara spesifik sangat rendah pada bidang profesi dan manajemen akan tetapi memiliki angka tinggi pada pekerjaan yang berketerampilan. Sebagai contoh, para penyandang disabilitas tunarungu lebih mengandalkan panca indera mata sebagai daya tangkap dalam memahami atau mempelajari sesuatu hal, dengan melihat apa yang dicontohkan dalam menjahit bermula dari memasukkan benang ke jarum, mulai menjahit sampai rapih itu semua dapat mereka lihat dan ikuti gerakan-gerakannya sampai mereka hafal. Menurut Mas Ali daya tangkap mereka cukup baik meskipun kekuatan daya ingatnya tidak semua sama tetapi ketika mereka sudah diberi pelatihan secara bertahap maka mereka dapat melakukannya dengan baik.

Pemberdayaan dengan memberikan pelatihan keterampilan dan pekerjaan sebagai pegawai ini selaras dengan yang dikatakan Hogan selanjutnnya dalam proses pemberdayaan yang berkesinambungan ialah mengidentifikasi proyek dan mengidentifikasi basis daya yang bermakna untuk melakukan perubahan. Keterampilan yang diberikan berupa keterampilan memasak, membuat dan menyajikan kopi atau makanan lain, melayani customer, menjahit, membuat souvenir. Pelatihan diberikan secara bertahap sampai akhirnya para disabilitas dapat bekerja sebagai pegawai kafe dan penjahit. Kemudian pelatihan ditambahkan dengan adanya pelatihan mencuci kendaraan, pelatihan diberikan melalui kerja sama dengan go Auto dimana para disabilitas di ajarkan mencuci motor dan mobil dengan mesin sehingga mereka bisa bekerja sebagai pencuci kendaraan di CAr WASh fingertalk.

Pemberdayaan juga didukung oleh beberapa komunitas yang membantu dalam menjalankan pemberdayaan dengan memberikan pelatihan seperti pelatihan menjahit, memasak, mencuci, dan lainnya. Pelatihan kemudian di implementasikan dengan memperkerjakan para disabilitas menjadi pegawai kafe, pembuat kopi dan roti, penjahit, dan pencuci kendaraan. Dengan itu maka ilmu yang di dapat langsung dipraktekkan dan para disabilitas mendapat pengalaman langsung menghadapi customer. Maka dengan ini akan semakin membantu proses pemberdayaan para disabilitas sehingga skill dan kepercayaan diri para disabilitas menghadapi customer akan semakin meningkat. 


\section{Mengembangkan rencana-rencana aksi dan mengimplementasikannya}

Penyandang disabilitas sebagai orang yang memiliki keterbatasan sering kali kurang mendapat perhatian khusus dan justru sering dianggap sebelah mata, dengan keterbatasannya dalam berkomunikasi merupakan hal yang membuat mereka sulit bersosialisasi dengan lingkungannya sehingga membuat mereka tidak dapat mengembangkan diri mereka sendiri dan tidak percaya diri.

Hal ini menjadi tujuan adanya Deaf Café and Car Wash Fingertalk dengan target dan harapan atas pemberdayaan yang dilakukan untuk para penyandang disabilitas khususnya tunarungu, sebagaimana yang dikatakan Mas Ali alasan memberdayakan tunarungu maka target atau harapan kepada para disabilitas supaya mereka mandiri dan adanya kesamaan atau kesetaraan antara disabilitas dan non disabilitas.

Tujuan adanya pemberdayaan ialah merujuk pada keadaan atau hasil yang ingin dicapai oleh sebuah perubahan sosial, yaitu masyarakat yang berdaya, memiliki kekuasaan atau mempunyai pengetahuan dan kemampuan dalam memenuhi kebutuhan hidupnya baik yang bersifat fisik, ekonomi maupun sosial seperti memiliki kepercayaan diri, mampu menyampaikan aspirasi, mempunyai mata pencaharian, berpartisipasi dalam kegiatan sosial, dan mandiri dalam melaksanakan tugas-tugas kehidupannya (Sipahelut, 2010). ${ }^{5}$ Sebagaimana dengan teori tersebut, dengan pemberdayaan yang diberikan membawa perubahan bagi para disabilitas, membuat mereka berdaya dengan skill yang dimiliki dan pekerjaan yang didapat sebagai pegawai kafe, pembuat roti, penjahit, dan pencuci kendaraan sehingga mereka dapat memenuhi kebutuhan hidupnya.

Dalam pelaksanaan pemberdayaan kepada para disabilitas, mba Dissa dan pengurus lainnya memberikan apa yang dibutuhkan para disabilitas di Deaf Café and Car Wash Fingertalk agar selalu berkembang baik secara pengetahuan, keterampilan, kepercayaan diri, dan penghasilan.

Sebagaimana yang dikatakan Kartasasmita bahwa pemberdayaan adalah

${ }^{5}$ Sipahelut, M. 2010. Analisis Pemberdayaan Masyarakat Nelayan Di Kecamatan Tobelo Kabupaten Halmahera Utara. Universitas Institut Pertanian Bogor. 
tindakan untuk meningkatkan kemampuan dan kemandirian yang dimulai dengan penciptaan suasana atau iklim yang memungkinkan potensi masyarakat menjadi berkembang. seperti yang telah dijelaskan sebelumnya, bahwa pemberdayaan yang dilakukan kepada disablitas ialah dengan memberikan motivasi untuk berubah, pelatihan keterampilan berupa keterampilan memasak, menyajikan pesanan, menghadapi customer, menjahit, membuat kopi, membuat roti, mencuci kendaraan. Pelatihan pertama kali diberikan ialah pelatihan memasak, menyajikan makanran, melayani customer. Pelatihan diberikan langsung oleh mba Dissa dan pengurus lainnya. Para disabilitas diajarkan dan dibimbing bagaimana menghadapi customer, berkomunikasi dan membangun percaya diri. Para disabilitas dibiasakan untuk mandiri dalam bekerja. Setelah kafe berjalan kemudian jumlah para disabilitas bertambah maka para disabilitas diberi pelatihan tambahan dengan tujuan agar para disabilitas dapat memilih bidang apa yang tepat bagi mereka sesuai dengan kemampuan mereka dan semakin beragam keterampilan yang mereka miliki.

Pelatihan keterampilan yang diberikan yaitu menjahit, merajut para disabilitas diajarkan dan dibimbing membuat kerajinan tangan seperti boneka, tempat tissue, dan ragam souvenir lainnya. Setelah berhasil menjadi pengrajin kerajinan tangan, disabilitas diberi pelatihan tambahan lagi yaitu mencuci kendaraan dengan mesin. Para disabilitas diajarkan dan dibimbing bagaimana menggunakan mesin untuk mencuci, bagaimana menggunakan hidrolik X dalam mencuci mobil. Pelatihan dilakukan oleh Mas Ali dan bekerja sama dengan go Auto salah satu program dari perusahaan ojek online.

Selain pengetahuan mengenai pekerjaan tetapi para disabilitas juga diberikan workshop keagamaan, belajar bahasa inggris, belajar bahasa isyarat untuk berkomunikasi dengan orang lain. Para disabilitas juga di fasilitasi tempat tinggal untuk mereka tinggal dan kendaraan operasional guna memudahkan pekerjaan mereka. dengan memberikan tempat tinggal dapat menjadi sarana bagi mereka untuk saling mengenal, dekat secara emosional, dan saling menyemangati. Maka dengan hal ini dapat membuat para disabilitas nyaman dan betah di Deaf Café and Car Wash Fingertalk serta 
tidak merasa diperlakukan tidak adil sebagai seorang disabilitas.

\section{B. Strategi Pemberdayaan}

Sebagaimana ciri-ciri pendekatan strategi (Moestopo, 1978) ${ }^{6}$ salah satunya ialah dengan memusatkan perhatian pada tujuan yang ingin dicapai serta gerak untuk mencapai tujuan tersebut. Dengan berfokus pada tujuan dari adanya pemberdayaan untuk para disabilitas maka mba Dissa dan pengurus lainnya berupaya membuat para disabilitas merasa nyaman dan semangat berada di Deaf Café and Car Wash Fingertalk ini dengan membuat suasana senyaman mungkin sebagaimana kenyamanan yang didapat di dalam rumah sendiri, tidak memberi kesan eksploitasi, kumuh, dan dengan menjaga senyum, menjaga mood para pengurus agar para disabilitas tetap nyaman bekerja disini. Selain itu, beberapa hal yang dijaga dan ditingkatkan agar pemberdayaan dapat berjalan dengan lebih baik, yaitu:

\section{Menguatkan dan memfasilitasi}

Dalam mencapai tujuan pemberdayaan kepada para disabilitas yang dilakukan mba Dissa dan pengurus sesuai dengan salah satu penerapan pendekatan pemberdayaan yaitu memperkuat pengetahuan dan kemampuan yang dimiliki masyarakat dalam memecahkan masalah dan memenuhi kebutuhan-kebutuhannya. Pemberdayaan harus mampu menumbuh kembangkakan segenap kemampuan dan kepercayaan diri masyarakat yang menunjang kemandirian mereka.

Sebagaimana yang telah dijelaskan sebelumnya dengan diberikan dukungan, motivasi agar semangat dalam melakukan perubahan terhadap diri mereka sendiri dan membuka pandangan para disabilitas bahwa mereka memiliki potensi yang dapat dilatih dan dikembangkan yaitu dengan melatih skill atau keterampilan serta melatih keberanian para disabilitas untuk berhubungan dan membuka diri dengan orang lain. Para pengurus Deaf Café and Car Wash Fingertalk sangat memperhatikan kenyamanan para disabilitas, ini sebagai salah satu strategi dalam melakukan pemberdayaan

\footnotetext{
${ }^{6}$ Moestopo, Ali. StrategiKebudayaan, Jakarta: CSIS, 1978
} 
untuk para disabilitas. Menurut Mas Ali, para disabilitas sulit mendapat pekerjaan dan merasa tidak percaya diri salah satu penyebabnya ialah karena tidak mendapatkan kenyamanan dilingkungan pekerjaan maupun diluar itu. Maka disini mereka diberikan kenyamanan dengan dihormati, dihargai, dan sabar dalam memberikan pemberdayaan kepada para disabilitas.

Selain motivasi dan pengetahuan, dengan diberikan fasilitas dapat mempermudah para disabilitas dalam bekerja juga sebagai tempat para disabilitas berkumpul membangun hubungan satu sama lain agar dapat saling terbuka dan saling menyemangati satu sama lain, dengan hal ini akan membuat mereka merasa nyaman dan bersemangat dalam melakukan perubahan.

\section{Meningkatkan pengetahuan, sikap, dan keterampilan}

Jadi upaya memberdayakan masyarakat dilakukan, selain dengan mendudukkan masyarakat sebagai aktor utama juga harus didukung dengan bantuan ekonomi serta membekali dengan berbagai ketrampilan dan pengetahuan. Wawasan pengetahuan dan ketrampilan yang dimiliki akan meningkatkan kreativitas yang akan membantu dalam pengambilan keputusan, melihat dan memanfaatkan peluang serta mengatasi kendala yang timbul dalam pelaksanaannya. Dengan demikian hasil yang diperoleh juga akan lebih baik.

Berbagai upaya pemberdayaan yang dilakukan pada masyarakat desa harus ditujukan untuk membentuk kemandirian. Bantuan ekonomis saja tanpa didukung kemampuan maupun kemauan untuk maju akan kurang bermanfaat. Setelah bantuan tersebut habis kegiatan pembangunan akan berhenti. Masyarakat yang mandiri memiliki kemampuan tidak saja untuk menikmati namun juga melestarikan dan secara terus menerus mengembangkan hasil pembangunan sehingga akan tercapai pembangunan yang berkelanjutan.

Pemberdayaan dilakukan dengan memberikan pelatihan keterampilan, keterampilan berupa membuat roti, menjahit, mencuci kendaraan, dan membuat kopi. Pelatihan diberikan tiga kali pertemuan oleh pelatih dalam bidangnya, pelatihan selanjutnya dibimbing oleh Mas Ali sebagai manajer operasional. Pelatihan diberikan kepada semua disabilitas sehingga semua dapat belajar dan 
memiliki skill yang beragam tetapi dalam menentukan pekerjaan dilihat dari bagaimana disabilitas lebih dominan dalam melakukan keterampilan.

\section{Meningkatkan dan pengembangan kemitraan dan jejaring kerja}

Dalam menunjang keberhasilan pemberdayaan membangun jejaring sosial dan mengembangkan kemitraan atau kerja sama merupakan hal yang penting dan sebagai strategi yang harus dipahami dalam pelaksanaan pemberdayaan. Dengan mengembangkan kemitraan dan jejaring kerja dapat berdampak kepada pemberdayaan yang diberikan untuk para disabilitas. Mba Dissa sebagai volunteer yang aktif dan banyak berkegiatan di luar maupun dalam negeri membuka jalan bagi terbentuknya kemitraan dengan jaringan yang lebih luas. Seperti yang disampaikan Mas Ali bahwa dalam mengembangkan pemberdayaan disabilitas terkadang mendapat kunjungan dan bantuan oleh Kedutaan New Zealand, Amerika dan dari dalam negeri yaitu Bank Permata Indonesia, BAZNAS, dan lainnya.

Dalam mengembangkan jaringan sosial Deaf Café and Car Wash Fingertalk selain dengan membuka stand di berbagai acara atau di pasar juga memanfaatkan kemajuan teknologi, dengan aktif di sosial media untuk mempromosikan hasil produk para disabilitas. Dengan meluasnya akses dan jangkauan pada sosial media kini banyak orang mengetahui tentang Deaf Café and Car Wash Fingertalk.

\section{Hasil Pemberdayaan}

Menurut Sulistiyani mengatakan tujuan pemberdayaan adalah sebagai berikut: "yang ingin dicapai dari pemberdayaan adalah untuk membentuk individu dan masyarakat menjadi mandiri. Kemandirian tersebut meliputi kemandirian berpikir, bertindak dan mengendalikan apa yang mereka lakukan tersebut (Sulistiyani, 2004). ${ }^{7}$

Pada tahap awal permasalahan kesejahteraan sosial yang dihadapi oleh masyarakat timbul pada umumnya dalam kerangka upaya memenuhi

\footnotetext{
${ }^{7}$ Sulistiyani, PemberdayAan MASyArakAt. Bandung: Grafindo, 2004.
} 
kebutuhan dasarnya (primary needs), karena mereka kurang mampu mengidentifikasi, menggali, mengerahkan dan mengarahkan potensi yang terdapat dalam lingkungan masyarakatnya baik yang bersifat alami, manusiawi maupun sosial. Sebagaimana dengan para penyandang disabilitas, dengan keterbatasan yang mereka miliki tidak hanya membuat mereka sulit berkomunikasi dengan orang lain tetapi juga sulit memahami diri mereka sendiri karena tidak adanya yang mengarahkan dan membimbing mereka untuk mencari kelebihan yang ada pada diri mereka, maka dengan ini mba Dissa dan pengurus lainnya memberikan pelatihan keterampilan untuk para disabilitas.

Keberhasilan pemberdayaan yang dilakukan mba Dissa dengan mendirikan sebuah kafe untuk para disabilitas tunarungu terlihat dari perubahan yang didapat oleh para disabilitas ialah dengan meningkatnya kesejahteraan dan kemandirian pada mereka. Kesejahteraan dan kemandirian yang terlihat dari para disabilitas ialah dengan membaik dan meningkatnya perekomonian mereka sehingga membuat mereka tidak lagi bergantung kepada keluarga atau orang lain bahkan dengan penghasilan yang mereka dapatkan dengan bekerja di Deaf Café and Car Wash Fingertalk ini dapat membantu anggota keluarga lainnya, seperti yang disampaikan Mas Ali bahwa dengan penghasilan rata-rata Rp 500.000 - Rp 900.000 sudah dapat memenuhi kebutuhan hidup para disabilitas bahkan dapat membantu anggota keluarga lainnya seperti yang disampaikan mas Rizky, dengan penghasilannya dari bekerja dapat memenuhi kebutuhan hidupnya dan dapat membantu kebutuhan sekolah keponakannya. Begitupun dengan para disabilitas yang sudah berkeluarga, mereka dapat memenuhi kebutuhan hidup keluarganya. Dengan bekal keterampilan yang diberikan, para disabilitas tidak hanya bekerja di kafe tetapi ada dari mereka yang memiliki pekerjaan tambahan terutama bagi yang telah berkeluarga seperti pak Agus agar memiliki pemasukan tambahan ialah dengan bekerja menjadi pencuci kendaraan di tempat lain dan menjadi penjahit dirumahnya bersama istrinya. 


\section{Keterampilan}

Hasil dari pemberdayaan yang diberikan kepada para disabilitas ialah membuat mereka memiliki wawasan pengetahuan dan keterampilan. Dengan wawasan pengetahuan dan ketrampilan yang dimiliki akan meningkatkan kreativitas yang akan membantu mereka dalam pengambilan keputusan, melihat dan memanfaatkan peluang serta mengatasi kendala yang timbul dalam pelaksanaannya. Dengan demikian hasil yang diperoleh juga akan lebih baik.

Keterampilan tidak hanya bekerja membuat kerajinan, memasak, atau mencuci tetapi juga bagaimana para disabilitas dapat mengendalikan emosinya, mengendalikan dirinya dari rasa tidak percaya diri, dan dapat membangun komunikasi dengan orang lain atau para cutomer. Sebagaimana menurut $\mathrm{La}$ France (Aly, 2017), ${ }^{8}$ soft skills atau keterampilan di definisikan sebagai perilaku personal dan interpersonal yang mengembangkan dan memaksimalkan kinerja seseorang terkait kepercayaan diri, fleksibilitas, kejujuran dan integritas diri. Seperti yang disampaikan para disabilitas bahwa sekarang mereka jadi memiliki keterampilan dan menjadikan mereka dapat percaya diri untuk berkomunikasi dengan orang lain.

Sebagaimana yang disampaikan Mas Ali bahwa sebelumnya para disabilitas tidak sadar dengan kelebihan mereka mengenai soft skills atau keterampilan maka disini mereka diarahkan, dibimbing, diajarkan mengenai soft skills atau keterampilan sehingga sekarang mereka dapat bekerja disini. Tidak hanya itu, sebelumnya para disabilitas juga sangat tertutup, tidak mau berkomunikasi dengan teman-temannya yang lain apalagi dengan customer tetapi setelah di motivasi, diberi bimbingan sekarang mereka mulai membuka diri untuk berkomunikasi dengan yang lain dan berani menghadapi customer. Ditambahkan oleh mas Ponirin bahwa kerja para disabilitas sangat baik dan bagus maka banyak diantara customer merasa puas dan tidak jarang yang memberikan tips atau upah tambahan serta acungan jempol kepada hasil kerjanya para disabilitas.

\section{Percaya diri dan kemampuan berkomunikasi dengan masyarakat}

${ }^{8}$ Abdullah Aly, Pengembangan Pembelajaran karakter berbasis Soft Skills di Perguruan Tinggi: ishraqi, Volume 1 No. 1 Januari2017) h. 40-51 
Dengan keterbatasan yang dimiliiki para disabilitas tunarungu membuat mereka kesulitan dalam berkomunikasi. Para disabilitas sulit memahami orang lain dengan bahasa verbal dan orang lain sulit menyampaikan atau memahami pesan dari para penyandang disabilitas sehingga hal ini membuat para penyandang disabilitas tidak percaya diri dan menutup diri dari bergaul dengan yang lain. Sebagaimana yang dijelaskan Mas Ali bahwa saat pertama kali para disabilitas datang dan mengikuti kegiatan pemberdayaan para disabilitas sangat tertutup dan pemalu tetapi oleh para pengurus terus di beri motivasi dan dipaksa untuk berkomunikasi dan menghadapi customer sampai akhirnya para disabilitas berani untuk menghadapi customer dan berkomunikasi dengan teman-teman lainnya.

Payne (Syamsir \& Amir, 2008) ${ }^{9}$ berpendapat bahwa, pemberdayaan adalah membantu klien memperoleh daya untuk mengambil keputusan dan menentukan tindakan yang akan ia lakukan yang terkait dengan diri mereka, termasuk efek hambatan pribadi dan sosial dalam melakukan tindakan. Hal ini dilakukan melalui peningkatan kemampuan dan rasa percaya diri untuk menggunakan daya yang ia miliki. Dengan meningkatnya kepercayaan diri para disabilitas membuat mereka lebih berperan dalam kehidupan mereka sendiri, mereka dapat memutuskan segala sesuatunya mengenai kehidupan mereka.

\section{Faktor Pendukung dan Penghambat}

\section{Faktor Pendukung}

Pelaksanaan pemberdayaan tidak akan berjalan dengan baik tanpa kerja sama yang baik dari semua pihak dan dukungan dari keluarga serta orang terdekat, hal itu merupakan energi terkuat dalam menjalankan pemberdayaan untuk para disabilitas bagi pemberdaya maupun yang diberdayakan.

Pemberdayaan yang dilakukan mba Dissa dalam mendirikan Deaf Café and Car Wash Fingertalk mendapat dukungan penuh dari keluarga dan hadirnya Ibu Pat Sulistyawati yang memberikan tempat di Pamulang sebagai tempat pemberdayaan pertama kali bagi disabilitas menjadi CAFe ANd

\footnotetext{
${ }^{9}$ Syamsir Salam, dan Amir Fadhilah, Sosiologi Pedesaan, (Jakarta: Lembaga
} Penelitian UIN Syarif Hidayatullah, 2008) h. 238. 
workshop pertama yang berdiri dan beroperasi. Selain itu Ibu Pat juga yang mengajarkan bahasa isyarat BISINDO kepada para pengurus.

Dalam menjalankan pemberdayaan berkaitan dengan pelatihan keterampilan dengan dibantu oleh beberapa pArtner sesuai bidangnya:

- Dalam belajar bahasa isyarat selain dengan ibu Pat juga dibantu oleh Plushindo play \& learn

- Dalam kegiatan lainnya di dukung juga dari New Zealand embassy dan Permata bank

- Dalam pARtner sesama pemberdayaan dengan Banua mombreta "rumah bertamu" dan pemberdayaan disabilitas dengan Fingertalk BW \& giftbaskets (Gaborone, Bostwana)

- Dalam pelatihan kopi dibantu oleh Sitro coffee

- Dalam pembuatan roti oleh Mbak Thie Santoso dan PT SAF Indonesia

Sebagaimana pada tujuannya, pemberdayaan dilakukan untuk para disabilitas maka tanpa hadirnya para disabilitas tidak akan berjalan pemberdayaan ini seperti yang disampaikan Mas Ali bahwa faktor pendukung utama ialah antusias para disabilitas yang ingin bergabung dengan DeAF CAFé ANd CAR WASh Fingertalk dan bagaimana para pengurus memilih orang yang tepat untuk diterima.

\section{Faktor penghambat}

Dalam berbagai pelaksanaan kegiatan tentu ada sesuatu hal yang menjadi penghambat dalam pelaksanaannya. Begitu juga dalam pemberdayaan yang dilakukan di Deaf Café and Car Wash Fingertalk. Faktor penghambat yang terjadi ialah sulitnya para disabilitas dalam berkomunikasi dengan customer. Rasa tidak percaya diri para disabilitas membuat para disabilitas malu untuk berkomunikasi dengan customer karena lebih sering dihadapkan pada customer yang tidak paham dengan bahasa isyarat atau berkomunikasi dengan disabilitas.

Para disabilitas juga merasa sulit dalam memahami apa yang diajarkan dalam melatih keterampilan karena sebagaimana yang telah disampaikan Mas Ali bahwa daya tangkap dan kecekatan para disabilitas 
tidak semua sama dan salah satu faktor penghambatnya ialah ketika para disabilitas sulit diajarkan karena tidak cepat dalam menangkap maksud yang disampaikan. Selain itu, tidak semua sesuai dengan permintaan dan harapan, ada disabilitas yang sesuai dari kemampuan tetapi malas-malasan, ada yang mau dan rajin tetapi kurang dalam kemampuannya maka hal tersebut menjadi PR bagi para pengurus DeafCafé and Car Wash Fingertalk. Maka dari itu peningkatan kemampuan berkomunikasi dengan disabilitas harus lebih ditingkatkan lagi supaya lebih mudah dalam membimbing para disabilitas.

\section{PENUTUP}

Hasil dari pemberdayaan yang dirasakan para penyandang disabilitas antara lain: pertama, meningkatnya kesejahteraan dan kemandirian para penyanadang disabilitas. Kesejahteraan dan kemandirian yang terlihat ialah dengan mereka tidak lagi bergantung kepada keluarga atau orang lain. Kedua, meningkatnya keterampilan pada penyandang disabilitas. Dengan keterampilan ini tidak hanya menjadikan para disabilitas memiliki skill tetapi juga membuat mereka menjadi bisa mengendalikan diri dari rasa tidak percaya diri dan dapat membangun komunikasi dengan orang lain.

Terdapat rekomendasi-rekomendasi yang peneliti tawarkan mengenai pemberdayaan penyandang disabilitas di Deaf Café and Car Wash Fingertalk Cinere, yaitu (1) Kepada semua pengurus Deaf Café and Car Wash Fingertalk agar mempertahankan kegiatan pemberdayaan untuk penyandang disabilitas yang nyaman dan membuat mereka merasa di perlakukan setara dengan non disabilitas.. Menambah jenis pelatihan keterampilan agar ketika disabilitas bertambah mereka dapat memilih lebih banyak pilihan untuk bekerja di bidang apa. Dan menambah jumlah serta jenis penyandang disabilitas lainnya yang ada di Indonesia supaya memiliki kesempatan di berdayakan dan di perkerjakan dengan baik sesuai keadaan mereka sehingga dapat mencetak lebih banyak penyandang disabilitas yang kreatif dann mandiri. (2) Kepada para penyandang disabilitas agar dapat menjaga semangatnya dalam belajar dan bekerja. Dan meningkatkan kreatifitas dalam keterampilan agar hasil keterampilan semakin baik dan berfariasi. 


\section{DAFTAR PUSTAKA}

Abdullah Aly, Pengembangan Pembelajaran karakter berbasis Soft Skills di Perguruan Tinggi: ishraqi, Volume 1 No. 1 Januari2017) h. 40-51

Barnes, Colin dan Geof Merer, Disabilitas: SuAtu PenGantar. Penerjemah: Siti Napsiyah,dkk. Jakarta: PIC UIN Jakarta, 2007.

Emzir,Metodologi penelitiAn kuAlitAtif: AnAlisis DAtA.Jakarta: Rajawali Press, 2010. Machendrawaty,Nanih dan Agus Ahmad Syafei, Pengembangan Masyarakat Islam Dari Ideology, Strategi. Bandung: PT Remaja Rosdakarya, 2001.

Manullang, Sastrawan ed., Community Development: AlterNAtif Pengembangan MaSyarakat di Era Globalisasi. Yogyakarta: Pustaka Pelajar, 2008.

Moestopo, Ali.Strategi KebudAyAAn. Jakarta:CSIS.1978.

Reefani, Nur Kholis. PAnduAn ANAk BerkebutuhAn Khusus. Yograkarta:Imperium, 2013.

Rukminto, Isbandi, Intervensi Komunitas PengembanGAn MaSyArAkAt SebaGai UPAyA PemberdayaAn Masyarakat. Jakarta: Raja Grafindo Persada, 2007.

Salam,Syamsir dan Amir Fadhilah, Sosiologi PedesAAn. Jakarta: Lembaga Penelitian UIN Syarif Hidayatullah, 2008.

Sarwono.,Jonathan.Metode Penelitian KuAntitatif dAn KuAlitatif.Yogyakarta:Graha Ilmu, 2006.

Suharto,Edi, Membangun MaSyArakAt MemberdayakAn RakyAt. Bandung:Rafika Aditama, 2010.

Sulistiyani, PemberdayAAn MaSyArakAt. Bandung: Grafindo, 2004.

Umar,Husein, Strategic MAMAgement in Action. Jakarta: PT Gramedia Pustaka Utama, 2001.

Yunus, Eddy, MANajemen Strategis. Yogyakarta:ANDI, 2006

Zubaedi, PENGEMBANGAN MASYARAKAT: WACANA dAn Praktik. Jakarta: KENCANA, 2013. 


\section{Undang -Undang}

Pasal 1 angka 1 Undang-Undang Nomor 4 Tahun 1997 tentang Penyandang Cacat, (Lembaran Negara Republik Indonesia Tahun 1997 Nomor 9, Tambahan Lembaran Negara Republik Indonesia Nomor 3670).

Undang-Undang Nomor 19 Tahun 2011 Tentang Pengesahan Hak-Hak Penyandang Disabilitas, (Lembaran Negara Republik Indonesia Tahun 2011 Nomor 107, Tambahan Lembaran Negara Republik Indonesia Nomor 5251)

Undang-Undang Nomor 8 Tahun 2016 Tentang Penyandang Disabilitas, (Lembaran Negara Republik Indonesia Tahun 2016 Nomor 69, Tambahan Lembaran Negara Republik Indonesia Nomor 5871)

Undang-Undang Nomor 8 Tahun 2016 Tentang Penyandang Disabilitas Pasal 27 ayat (2) UUD 1945 dan Pasal 28D ayat (2) UUD 1945 